16. 評

\section{7 成就値の妥当性について}

金 井 達 蔵(横浜国立大学)

批判のある成就值の妥当性を（1）成就值と知能偏差 值との 相関, (2) 成就值相互の 相関の 2 つから検討し た。中 2,270 名に知能, 学力検査各 2 種を課した。(1) 理論式からー0.35〜-0.46 となつた。(2) 知能, 学力と もに異なるとき，学力の久異なるとき，知能のみ異なる ときでは平均相関係数はそれぞれ $0.36,0.81 ， 0.56$ であ つた。

\section{MMPI による防衛尺度の作成}

戸 荻 正人(愛猨大学)

防衛行動の研究のために, 脅威に対する反応傾向（回 避と接近）を弁別する測定道具の作成を試みた。Byrne の Repression-Sensitization Scale (MMPI の 156 項 目）の項目分析の結果，81 項目による防衛尺度，扣よ び 30 項目による短縮版を作成し，信頼性と妥当性を吟 味した。

\section{9 テスト不安に関する研究（1)}

上田 順一(島根大学)

Sarason, I. G. の「テスト不安尺度」を用いて児童か ら大学生に至る 2585 人のテスト不安を測定した。各学 年を通じて女子は男子ょり高い得点を示した。この傾向 は都市・田舎別にみても同様であつた。また男子も女子 も田舎のものが都市のものよりもそれぞれ高い得点を示 すことがわかつた。とくに田舎の女子に扒いて顕著であ る。

\section{0 巟童, 生徒の欲求不淽に関する研究}

○藤井悦雄・扇田博元 (大阪府科学教育センター) 欲求不満の量および質を，子供たちを取りまく環境諸 条件との関連において質問紙法により調査した結果, 欲 求不満は, 子供の年令的発達により莫然とした対象から 明確な対象に向かい，それぞれの環境条件の特性によつ て，それぞれ一定の傾向をもつた働き方をすることが判 つた。なお，調査は結果の分析に基ずき改訂中である。

\section{Rorschach 反応の投影性に関する研究 一投影形式からみた刺激特性一}

○江 見 佳 俊(愛知学院大学)

村上英治(名古屋大学)

Rorschach 反応がパーソナリテイを投影する程度を， positive, neutral, negative の 3 種の投影形式として設 定し, 各刺激に示された反応を分析した。結果として各 投影形式をとる反応の出現可能性は各刺激で異なり， 一般に客観的意味構造をもつ刺激で positive projection の反応が出現しやすいことが認められた。

\section{討 論 の 概 要}

\section{部会の特徵}

この部会では 5 つの砋究発表が行われた。これを大別 すると 3 群に分けられる。第 1 群は, 金井 (327), 戸苅 (328), 江見ら (331) の諸研究で, テストの妥当性, 信 頼性に関する研究であり, 第 2 群は, 上田 (329) のテ スト事態に対する研究であり, 第 3 群は藤井ら (330) の欲求不満に対する研究であつた。本部会においては, 第 2 群の研究を中心に, 第 1 群の研究と合わせて, テス 卜事態の問題がもつとも多く討議された。

全体的に云つて，ここで行われた討議では，テストの 妥当性及び信頼性の問題に始まり, テストに括ける個人 の生理, 心理的問題から,テスト事態に打ける社会的問 題に至るまでの広範囲な要因が取上げられ，テスト施行 に当つて考慮されなければならない諸問題が各研究を通 して討議された。

\section{テストの妥当性, 信頼性}

戸苅は，MMPI による防衛尺度の作成について 発表 したが，これに対し，永沢（埼玉大）は，防衛性といら 概念はどんなものであり，どうして MMPI の項目を用 いたかを質疑した。すなわち，防衛性の測定が MMPI において得られる共通傾同からだけで十分に測定できる であろらかといら妥当性の問題であつた。これに対し， 発表者から, 防衛性を, 脅威に対する反応の違いによつ て測定しょうとしたとの答弁があつた。このことは， MMPI に执いて見出される2つの反応傾向群があり， それは，接近的反応と回避的反応で，この 2 つを防衛性 の型としたのであると考えられた。これに対して，更に 討議が続けられた。その結果次のような結論が見出され た。すなわち，新しい尺度形成の場合，既成の尺度から 項目を選ぶ場合は，特に，新しい尺度の概念規定を明確 にした上でとりかかる必要があり, 新しい尺度の妥当性 を常に考慮に入れて研究に当るべきであろう，というこ とであつた。

上田は，テスト不安に対する研究を発表したが，これ に対し，岡田（東大）は，この尺度の適用範囲を聞き， 児童の発達段階と，身体的生理的条件によつて，反応傾 
向が違らのではないかと指摘した。この問題は, 戸萠の 研究だけでなく, 他の研究にも当てはまる問題であり, いろいろ討議がなされたが，結論としては，テスト作成 や，その施行に当つて，身体的，生理的条件について も，妥当性と信頼性の範囲を定めておく必要があること が認められた。

江見らは、ロールシャッハ反応の投影性に関する研究 を発表した。ここでは，ロールシャッ八図版の提示によ る反応測定と，同じ図版のスライド投射による集団反応 の測定とが行われたが，これに対し，上田（島根大）は スライドとカードとの反応は違うのではないかと指摘し た。この問題も, テストの妥当性と信頼性の問題に関す るものだと考えられる。これに対し, 発表者より, カー ドとスライドとの反応は最初より違うものとして，それ ぞれ，別個に取扱つたとの答弁がなされた。

以上, テストの妥当性と信頼性について, 各研究を通 して, 活発な討議が行われた。

\section{テスト事態}

上田は，テスト不安に関する研究を発表したが，これ に対し, 田畑（京都大）は, ここで用いられたテスト不 安尺度の反応は，文章読解という手段を通して得られた ものであつて, 測定しょらとしている本来のテスト不安
が得られるであろらかといら問題を提示した。また，戸 荻（愛媛大）は，テスト不安と一般不安との関係といら 問題を提示した。これらの問題は, テスト事態と反応と の関係に関する問題である。これらの問題に対して, 発 表者から, 特定場面の不安と一般不安との関係はあまり ないとの答弁があつた。また，ロールシヤッ八Test 等 の場合と，質問紙法の場合でも不安は違うであろうとの 回答があつた。更に，この問題について討議がなされ， 被験者の緊張度なども大きな要因として考えねばならな いことが指摘された。

以上の討議から考えられ得ることは，テスト事態と反 応との関係については，1）検査者側，2）被験者側,

3）テストの場, の3つの問題が考慮さればならないと いらことである。

な报，藤井らの，児童生徒の欲求不満についての研究 については, テストの問題とは関係が薄かつたが, 研究 に用いられた被験者の種類などについて，テスト事態の 問題と合せて討議がなされた。

以上，本部会では，討議全体を通じて，テスト作成， 及び施行に当つて考慮しなければならない諸条件につい て, 熱心な討議がなされ，今後の研究に大いに役立つむ のであつた。

（原岡一馬）

\section{7. 教育環境・社会}

\section{1-403 双生児による人格形成の研究 (III)}

双生児の友人関係の発達

(1)三木安正・ (2)久原恵子・ (3)江口恵子

波多野誼余夫・乾侑美子(東京大学)

(1)

目的：質問法により，中 1 から高 3 までの双生児及び 一般児の友人関係の差異をみる。結果: 双生児において は一般児に拈けるほど友人関俰は発達していない。特 に, 友人の重要性が增してくると思われる高校生になる と，双生児での友人関係の発達の㧤くれが一層顕著にな る。

(2)

目的：友人関係の質的なちがいを調べるために，SD 法と $\mathrm{Q}$ 分類を行う。結果: 双生児では一番親しい友人 との関係の 発達が一般児よりおくれているだけではな く，二番目に親しい友人，普通の友人などとの関係はさ らに発達していないと考えられる。

\section{(3)}

目的：その 1，2で出された差異が何によるのか，そ の手がかりを得る。結果: 友人関係の発達していないも のには, 友人の役割が明確になつていないもの, 及び対

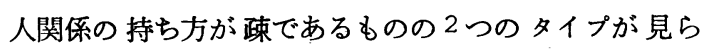
れ，対の相手がきようだいでもあり友人でああるという 双生児では，第一のタイプになる可能性が大である。

\section{4 親と子の相互作用の粎続的研究}

牛島義 友(九州大学)

親子関係をみるために保育者（親）と子どもの相互交 渉の行動を 3 力年にわたつて継続観察した。又施設と家 庭に拈ける相違，家庭間の相違等についてもしらべた。 家庭では施設よりも多くの相互交渉が見られ，特に直接 生活に必要でない無用な行動が多く，それが健全な性格 形成に役立つておる。 